\title{
Economic and Environmental Analyses of Multi-Generation Renewable Energy System for Dairy Farms
}

\author{
Matthew A. Cuomo ${ }^{1}$, Eric D. Kool ${ }^{1}$, Bale V. Reddy ${ }^{1 *}$, Marc A. Rosen ${ }^{1}$
}

${ }^{1}$ Faculty of Engineering and Applied Science, University of Ontario Institute of Technology, Oshawa, Ontario L1H7K4, CANADA
${ }^{*}$ Corresponding Author: Bale.Reddy@uoit.ca

Citation: Cuomo, M. A., Kool, E. D., Reddy, B. V. and Rosen, M. A. (2022). Economic and Environmental Analyses of Multi-Generation Renewable Energy System for Dairy Farms. European Journal of Sustainable Development Research, 6(1), em0174. https://doi.org/10.21601/ejosdr/11397

\section{ARTICLE INFO}

Received: 6 Dec. 2020

Accepted: 28 Dec. 2020

\begin{abstract}
In the present work, economic and environment analyses of multi-generational micro gas turbine systems are reported for a grid-independent dairy farm in Ontario, Canada. Onsite anaerobic digesters utilize farm waste to produce carbon neutral biogas for combustion in the micro gas turbine modules. A range of micro gas turbines coupled with absorption refrigeration units and an organic Rankine cycle are driven by the recovered waste heat to meet the cooling and electrical needs of farm sizes between 250 and 6000 cows. Farms of these sizes are observed to be capable of having their cooling and electricity needs met with micro gas turbines ranging in capacity from 100 to $1000 \mathrm{~kW}$ output. Environmental performance is maximized when the net output of the system just matches the energy requirement of the farm, and produces no excess electricity. Thus to minimize the environmental impact, but remain financially viable, various configurations are suggested for farm sizes under 2000 cows.
\end{abstract}

Keywords: renewable energy, dairy farm, multi-generation, economic analysis, environmental analysis

\section{INTRODUCTION}

From consumers' point of view, there is growing interest for companies to produce products that are eco-friendly over their life cycles (Collins, 2011). A feature of such products often is that all processes in the production operation are powered by net-zero carbon emission energy sources. Accordingly, dairy farmers producing milk or related products may be expected to operate using net-zero carbon emission energy sources (Loo and Koppejan, 2010). The opportunity arises to create multi-generation modular energy systems for farms desiring to convert to grid-independent, renewable means of powering their facilities.

Much work has been done in this field. A detailed thermodynamic analysis and optimization of an anaerobic treatment system for whey has been reported (Spachos and Stamatis, 2011). The impact of food production processes, in terms of energy utilization and carbon dioxide emissions, in a flavored yogurt production process was investigated (Sorguven and Ozilzen, 2012). A thermodynamic analysis of a milk pasteurization process assisted by geothermal energy was investigated (Yildirim and Zenc, 2015). The performance of a milk powder production system was investigated thermodynamically and the greatest exergy destruction was observed in the evaporator (Yildirim and Zenc, 2017). A systematic mapping of the current literature related to environmental, economic and social sustainability in dairy farms was carried out (Segerkvist et al., 2020]. The effects were assessed of improved performance in the U.S.A. dairy cattle industry on environmental impacts during the period 2007 to 2017 (Capper and Cady, 2020).

In the present study, economic and environmental analyses are performed for an integrated multi-generational system for a dairy farm based on renewable energy, which has previously been assessed with energy and exergy analyses (Cuomo et al., 2018a, Cuomo et al., 2018b). System configurations that can satisfy the energy demands of various farm sizes are considered. The integration of an ammonia based organic Rankine cycle (ORC) to generate power from the exhaust gas exiting the absorption refrigeration system (ARS) heat exchanger to generate additional electrical power is considered.

Due to the nature of the problem several constraints are placed on the system design:

1. The energy demand of the farm must come directly from the biomass energy generation system. This implies that only electricity generated by the unit in excess of the farm's own electricity requirements can be sold to the grid, as the electricity used to operate the farm operation must be $100 \%$ from a carbon-neutral source. 
Table 1. Energy demands for selected farm sizes

\begin{tabular}{ccccc}
\hline $\begin{array}{c}\text { Farm size } \\
{[\text { cows] }}\end{array}$ & Total & Without milk cooling load & $\begin{array}{c}\text { Thermal cooling demand } \\
{[\mathbf{k W} \text { cooling] }}\end{array}$ & $\begin{array}{c}\text { Number of 50 kW ARS units to } \\
\text { meet cooling load }\end{array}$ \\
\cline { 2 - 3 } & 28.75 & 22.7 & 13.6 & 1 \\
\hline 250 & 57.5 & 45.4 & 27.2 & 1 \\
\hline 500 & 115 & 90.9 & 54.3 & 2 \\
\hline 1000 & 172.5 & 136.3 & 81.5 & 2 \\
\hline 1500 & 230 & 181.7 & 108.7 & 3 \\
\hline 2000 & 460 & 363.4 & 217.4 & 5 \\
\hline 4000 & 690 & 545.1 & 326.0 & 7 \\
\hline 6000 & & & & \\
\hline
\end{tabular}

Data Source: (Clarke and House, 2010)

Table 2. Configurations considered and technical specifications of selected MGT modules (Capstone turbine Corporation, 2012; Turbec, 2012)

\begin{tabular}{ccccc}
\hline \multirow{2}{*}{ Manufacturer } & \multirow{2}{*}{ Turbine model configuration } & \multicolumn{2}{c}{ Performance parameter } \\
\cline { 3 - 5 } & & Capacity $(\mathbf{k W})$ & Exhaust temperature $\left({ }^{\circ} \mathbf{C}\right)$ & Exhaust flow rate $\left(\mathbf{k g ~ s} \mathbf{s}^{\mathbf{1}}\right)$ \\
\hline Turbec & T100CHP & 100 & 270 & 0.80 \\
\hline Capstone & 2 X C65 & 130 & 309 & 0.98 \\
\hline Capstone & 3 X C65 & 195 & 309 & 1.47 \\
\hline Capstone & C200 & 200 & 280 & 1.30 \\
\hline Capstone & 4 X C65 & 260 & 309 & 2.96 \\
\hline Capstone & C400 & 400 & 280 & 4.00 \\
\hline Capstone & C600 & 600 & 280 & 5.30 \\
\hline Capstone & C800 & 800 & 280 & 6.70 \\
\hline Capstone & C1000 & 1000 & 280 & \\
\hline
\end{tabular}

2. All of the dairy farm's current energy demand (Table 1) must be met via the integrated multi-generational system based on renewable energy.

\section{BACKGROUND}

This investigation extends research previously reported by the authors (Cuomo et al., 2018a, Cuomo et al., 2018b) on using integrated multi-generation energy system for a dairy farm, by carrying out economic and environmental analyses of the system. In the previous work, it was found that micro gas turbines could be utilized effectively to meet the electrical and cooling demands of dairy farms in Ontario, Canada, for farms of various sizes, based on the typical electricity use of an Ontario dairy farm (Clarke and House, 2010). The electricity and cooling demands for various Ontario farm sizes are listed in Table 1.

With the electricity and cooling demand of the dairy farm specified, appropriate MGTs and quantities of ARS units are selected to meet the electrical and cooling load requirements for the various farm sizes identified in Table 1.

The MGT modules selected for this particular study are manufactured by Turbec and Capstone. The capacities along with exhaust temperature, and exhaust flow rate for each of the MGT modules are listed in Table 2.

\section{SYSTEM MODELLING}

The system and its subsystems are modelled thermodynamically using EES and Excel software. The ambient conditions are taken to be $25^{\circ} \mathrm{C}$ and $101 \mathrm{kPa}$, and these are selected to be the conditions of the dead state.
Several general assumptions are invoked to simplify the assessment, while subsystem specific assumptions are listed at the beginning of the corresponding sections. The general assumptions are as follows:

1. Operation is at steady state.

2. Ideal gas models are applicable.

3. Electromechanical conversion losses are negligible.

4. Changes in kinetic and potential energy are negligible.

A general energy rate balance, which can be applied to each system component, can be written as:

$$
\dot{Q}_{\text {in }}+\dot{W}_{\text {in }}+\sum_{\text {in }} \dot{m} h=\dot{Q}_{\text {out }}+\dot{W}_{\text {out }}+\sum_{\text {out }} \dot{m} h
$$

where $\dot{Q}$ and $\dot{W}$ denote the heat and electrical work rates respectively, while $\dot{m}$ and $h$ are the mass flow rate and specific enthalpy of the working fluid respectively.

\section{Topping Cycle Model}

The MGTs are modelled thermodynamically with EES utilizing manufacturer technical specifications, including operating pressures, fuel flow rate, electrical efficiency, exhaust gas flow rate, exhaust temperature, and turbine inlet temperature (Capstone Turbine Corporation, 2012; Turbec, 2012).

In order to model the turbine modules according to the given specifications, the effectiveness of the regenerator as well as the isentropic efficiencies of the compressor and turbine are required. The effectiveness of the regenerator is taken to be $84 \%$, and the turbine and compressor isentropic efficiencies are both taken to be $72 \%$.

The compressor increases the air temperature and pressure. The air is heated as it enters the regenerator by the hot flue gases from the turbine exhaust, which enter the opposite end of the regenerator, in a counter flow 
Table 3. System state point parameters

\begin{tabular}{|c|c|c|c|c|c|}
\hline \multirow{2}{*}{$\begin{array}{l}\text { State } \\
\text { point }\end{array}$} & \multicolumn{2}{|r|}{ Flow information } & \multicolumn{2}{|c|}{ State properties } & \multirow{2}{*}{ Notes } \\
\hline & Composition & Details & $\mathbf{T}\left[{ }^{\circ} \mathbf{C}\right]$ & $\mathbf{P}[\mathrm{kPa}]$ & \\
\hline 1 & Air & Ambient conditions & 25 & 101 & $\begin{array}{c}\text { Intake drawing at } \\
\text { atmospheric pressure }\end{array}$ \\
\hline 2 & Air & Calculated by model & Variable & 552 & \multirow{3}{*}{$\begin{array}{l}\text { Outlet of compressor, } \\
\text { from technical } \\
\text { specifications* }\end{array}$} \\
\hline 3 & Air & Calculated by model & Variable & 552 & \\
\hline 4 & Combustion gases & Specified by technical specifications of turbine* & 950 & 552 & \\
\hline 5 & Combustion gases & Calculated by model & Variable & 101 & \multirow{4}{*}{$\begin{array}{c}\text { Exhaust at atmospheric } \\
\text { pressure }\end{array}$} \\
\hline 6 & Exhaust gas $\dagger$ & Set by turbine exhaust conditions & Variable & 101 & \\
\hline 7 & Exhaust gas $\dagger$ & Calculated by model, depends on \# of ARS units & Variable & 101 & \\
\hline 8 & Exhaust gas $\dagger$ & To prevent component damage & 150 & 101 & \\
\hline 9 & Water & Required inlet water temp. for ARS* & 105 & 169 & \multirow{2}{*}{ ARS water pressure ${ }^{* * *}$} \\
\hline 10 & Water & Specified water outlet temp. for ARS* & 115 & 169 & \\
\hline 11 & Ammonia & Calculated by model & 45.6 & 3830 & \multirow{4}{*}{$\begin{array}{c}\text { Recommended operating } \\
\text { pressures for an } \\
\text { optimized ammonia } \\
\text { based ORC } * *\end{array}$} \\
\hline 12 & Ammonia & Required inlet ORC turbine inlet temperature ${ }^{* * *}$ & 77 & 3830 & \\
\hline 13 & Ammonia & Recommended condensation temperature ${ }^{* * * *}$ & 45 & 1780 & \\
\hline 14 & Ammonia & Recommended condensation temperature ${ }^{* * * * *}$ & 45 & 1780 & \\
\hline
\end{tabular}

†Modelled as air

*Data source (Capstone Turbine Corporation, 2012; Turbec, 2012)

**Data source (Solar Next, 2008)

***:Source (Hettiarachchia et al, 2006)

configuration. The compressed air reaches the maximum cycle temperature with the firing of biogas in the combustion chamber. The hot combustion gases then expand through the turbine, which is connected to an electrical generator. The high temperature exhaust gases pass through the regenerator to provide preheating to the high pressure stream before being released to the atmosphere.

Assumptions regarding modelling of the topping cycle follow:

1. The compressor, combustion chamber and turbine are adiabatic.

2. All components except the compressor and turbine have negligible pressure drops.

3. Fuel entering the combustion chamber only contains chemical energy and exergy.

4. The specific heat ratio $\mathrm{k}$ is fixed at 1.4.

The work input rate to the compressor is:

$$
\dot{W}_{M G T, C O M P}=\dot{m}_{A}\left(h_{2}-h_{1}\right)
$$

The heat loss rate of the regenerator is:

$$
\dot{Q}_{L O S S, R E G E N}=\dot{m}_{A}\left(h_{2}-h_{3}\right)-\dot{m}_{g a s}\left(h_{5}-h_{6}\right)
$$

The heat input rate to the combustion chambers is:

$$
\dot{Q}_{C C}=\dot{m}_{g a s} h_{4}-\dot{m}_{A} h_{3}-\dot{m}_{f} h_{f}
$$

The work rate produced by the turbine is:

$$
\dot{W}_{M G T, T U R B}=\dot{m}_{g a s}\left(h_{4}-h_{5}\right)
$$

\section{Combustion Modelling}

Using manufacturer technical specifications, the parameters of each component are identified and analyzed. The heat input rate required by the combustion chamber $\dot{Q}_{c c}$ can be expressed as:

$$
\dot{Q}_{C C}=\dot{m}_{f} \cdot q_{L H V}
$$

where $\dot{m}_{f u e l}$ is the mass flow rate of fuel and $q_{L H V}$ is the lower heating value of biogas, which is taken to be $22000 \mathrm{~kJ}$ $\mathrm{kg}^{-1}$ (Loo and Koppejan, 2010).
A mass rate balance for the combustion chamber yields:

$$
\dot{m}_{g a s}=\dot{m}_{A}+\dot{m}_{f}
$$

The biogas for this study is taken to be a mixture of $60 \%$ methane, $35 \%$ carbon dioxide and $5 \%$ nitrogen. The biogas and its combustion are modelled as follows:

$$
\begin{aligned}
a \mathrm{CH}_{4}+b \mathrm{CO}_{2}+c \mathrm{~N}_{2} & +d\left(\mathrm{O}_{2}+3.76 \mathrm{~N}_{2}\right) \\
& \rightarrow e \mathrm{H}_{2} \mathrm{O}+f \mathrm{fCO}_{2}+g \mathrm{~N}_{2}+h \mathrm{O}_{2}
\end{aligned}
$$

Equating coefficients utilizing the air fuel ratio yields:

$$
\begin{aligned}
& a=0.6 \\
& b=0.35 \\
& c=0.05 \\
& d=m_{B G} \cdot A F_{B G} \cdot \frac{1}{M_{A}} \\
& e=2 a \\
& f=a+b \\
& g=c+3.76 d \\
& h=b+d-\frac{e}{2}-f
\end{aligned}
$$

where $A F_{B G}$ is the air-fuel ratio of the biogas.

\section{Bottoming Cycle Model}

An EES model for the bottoming cycle is developed to assess subsystem behaviour for various configurations, with different heat inputs from the various micro turbine exhaust streams. The number of ARS units required to meet the cooling load can be varied in the model, allowing determination of how much energy can be recovered after the ARS units for additional electricity generation with the considered ORC.

Fluid properties in the system are determined using EES fluid property information. The state point properties of the bottoming cycle are listed in Table 3.

Additional assumptions regarding modelling of the bottoming cycle follow:

1. All system components are adiabatic and, except for the pump and turbine, have negligible pressure drops.

2. The exhaust gas is modelled as air. 
3. Turbine and pump isentropic efficiencies within the ORC are $89 \%$.

4. Heat exchangers are $100 \%$ efficient.

5. The ARS heat exchanger is modelled as a single heat exchanger regardless of the number of ARS units employed. Thus, it is assumed the sum of all the water flows required by the ARS units pass through the heat exchanger, are heated to the required temperature, and then branched off to $n$ smaller streams feeding $n$ ARS units.

Operational constraints on the system parameters follow:

1. The temperature of the exhaust gas leaving the system (state 8) is set at $150^{\circ} \mathrm{C}$ to avoid water vapor condensation and formation of corrosive liquids that may damage components.

2. The ARS subsystem consists of $n_{A R S}$ Chillii ACC50 ARS units for a given configuration. If the available energy content of the exhaust gas stream is insufficient to power all $n_{A R S}$ ARS units for a given configuration, the configuration is considered unusable.

3. All farms can produce enough manure to generate the required quantity of biogas to operate all turbines continuously throughout the year.

\section{Organic Rankine cycle}

The work output rate of the ORC turbine can be expressed as:

$$
\dot{W}_{O R C, T U R B}=\dot{m}_{O R C}\left(h_{12}-h_{13}\right)
$$

and the work input rate to the pump a is:

$$
\dot{W}_{O R C, P U M P}=\dot{m}_{O R C}\left(h_{11}-h_{14}\right)
$$

Also, the energy extraction rate by the ORC from the exhaust gas is:

$$
\dot{Q}_{O R C, H X}=\dot{m}_{O R C}\left(h_{12}-h_{11}\right)
$$

while the energy rejection rate from the ORC condenser is:

$$
\dot{Q}_{O R C, C O N D}=\dot{m}_{O R C}\left(h_{13}-h_{14}\right)
$$

and the net electrical work output rate from the ORC is:

$$
\dot{W}_{O R C, N E T}=\dot{W}_{O R C, T U R B}-\dot{W}_{O R C, P U M P}
$$

\section{Absorption refrigerator}

The energy extraction rate by the ARS from the exhaust gas can be expressed as:

$$
\dot{Q}_{A R S}=\dot{m}_{A R S}\left(h_{10}-h_{9}\right)
$$

while the mass flow rate of water in the ARS subsystem is:

$$
\dot{m}_{A R S}=2.08 \times n_{A R S}
$$

where $n_{A R S}$ is the number of $50 \mathrm{~kW}$ ACC50 ARS units in a considered configuration.

The energy efficiency for the MGT module can be expressed as:

$$
\eta_{T C, I}=\frac{\dot{W}_{M G T, N E T}}{\dot{Q}_{C C}}
$$

where the net work output of the MGT module is:

$$
\dot{W}_{M G T, N E T}=\dot{W}_{M G T, T U R B}-\dot{W}_{M G T, C O M P}
$$

The energy efficiency can be written for the bottoming cycle as:

$$
\eta_{B C, I}=\frac{\dot{W}_{O R C, N E T}+\dot{Q}_{c o o l}}{\dot{m}_{g a s}\left(h_{6}-h_{8}\right)+3 n_{A R S}}
$$

and for the overall system as:

$$
\eta_{s y s}=\frac{\dot{W}_{M G T, N E T}+\dot{W}_{O R C, N E T}+\dot{Q}_{c o o l}}{\dot{Q}_{C C}+3 n_{A R S}}
$$

The performance based on energy and exergy analyses conducted and the results and details for the integrated multigeneration energy system for a dairy farm shown in Figure 1 are reported in previous publications (Cuomo et al., 2018a, 2018b).

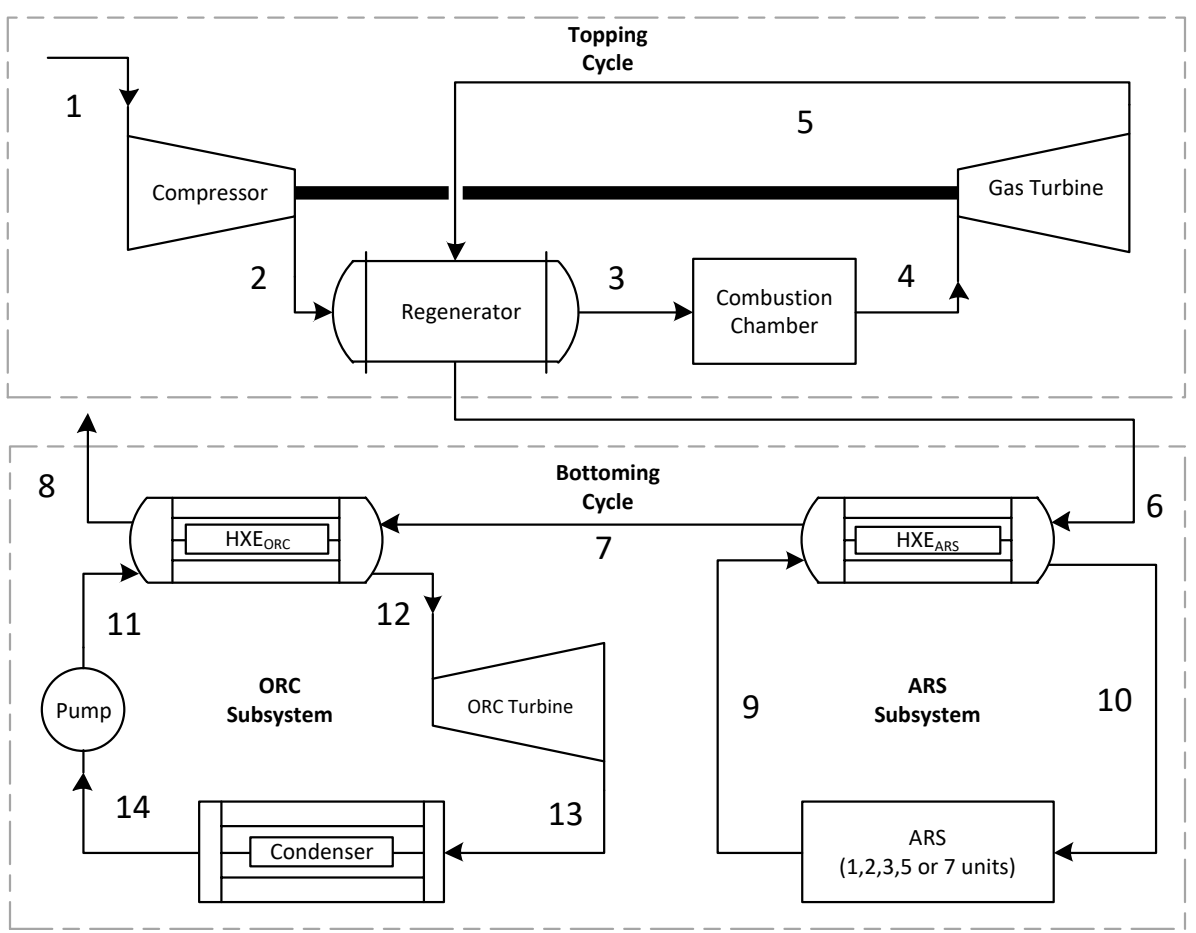

Figure 1. System layout of topping and bottoming cycles with ORC and ARS subsystems 
Table 4. FIT selling price schedule for Farm Biogas Projects, at the time of the study. Adapted from (Ontario Power Authority, 2012)

\begin{tabular}{cc}
\hline Capacity [kW] & FIT Selling Price [\$/kWh] \\
\hline$<100$ & 0.195 \\
\hline $100-250$ & 0.185 \\
\hline $250-500$ & 0.160 \\
\hline $500+$ & 0.147 \\
\hline
\end{tabular}

Table 5. Grid price schedule from Hydro One. Adapted from (Hydro One, 2012)

\begin{tabular}{ccc}
\hline Time & Grid Price [\$/kWh] & \% of time \\
\hline Off Peak & 0.063 & $50 \%$ \\
\hline Mid Peak & 0.099 & $25 \%$ \\
\hline On Peak & 0.118 & $25 \%$ \\
\hline Averaged Price & 0.08575 & $100 \%$ \\
\hline
\end{tabular}

\section{ECONOMIC ANALYSIS}

The feasibility of implementing the system largely depends on the economics of the project. In this section, the feasibility of implementing the proposed system on different farms is evaluated through a study of the net present value (NPV) of the project. This study breaks down the economics into two parts. First, the NPV of implementing each micro turbine unit with of compatible numbers of ARS units is evaluated, as these components are necessary for meeting the farm's energy requirement. Secondly, the NPV of electricity generated by the ORC unit is calculated to illustrate the economics of combining this unit as an add-on to produce additional electricity for profit.

\section{Sale of Electricity}

The capacity range for the systems considered is eligible to participate in Ontario Power Authority's (OPA's) Feed in Tariff (FIT) Program, at the time the study was undertaken. In accordance with the constraints of the problem, electricity generated by the system in excess of the farm's own energy requirement can be sold to the grid under a price schedule set by the OPA for a farm biogas project as shown in Table 4.

By implementing the new system, electricity no longer needs to be purchased from the grid. Thus a cost savings of the farm's original energy consumption can be realized by multiplying the farm's energy consumption by the time averaged price of electricity in Table 5 .

For calculations considering the ARS system only, the system net electricity rate is:

$$
\dot{W}_{N E T}=\dot{W}_{M G T, N E T}-3 n_{A R S}
$$

Referring to Table 1, the amount of saleable electrical power can be expressed as follows:

$$
\begin{aligned}
& \dot{W}_{S A L E A B L E} \\
& =\dot{W}_{S Y S, N E T} \\
& \text { - Farm Electricity Demand Sans Milk Cooling Electrical Load }
\end{aligned}
$$

The revenue from selling excess electricity can be written as:

$$
\begin{gathered}
\text { Sales }_{F I T}=\dot{W}_{\text {SALEABLE }} \times \text { Rate from Table } 4 \\
\cdot\left|\frac{8760 h}{1 \text { year }}\right|[\$ / \text { year }]
\end{gathered}
$$

The annual financial saving through implementing the system can then be determined as:

$$
\begin{aligned}
\text { Saving }_{G R I D}= & \text { Original Electricity Demand } \\
& \times \text { Rate from Table } 5 \\
& \cdot\left|\frac{8760 h}{1 \text { year }}\right|[\$ / \text { year }]
\end{aligned}
$$

\section{Net present value}

The net present value of a project is a meaningful way to determine its feasibility and profitability. The net present value can be evaluated for a project by considering it as a series of cash inflows and outflows.

The net present value of the project can be calculated as a sum of discounted cash flows over a period of time as follows:

$$
N P V(i, N)=\sum_{t=1}^{N} \frac{R_{t}}{(1+i)^{t}}
$$

where $i$ denotes the discount rate for projects of similar risk, $R_{t}$ the net cash flow from the project at time $t, N$ the number of periods, an $t$ the period in which the cash flow occurs.

For purposes of the FIT project considered here, the period $N$ is taken to be 20 years (the life of the contract) and the cost of capital is considered to be $10 \%(i=0.1)$.

\section{Calculations for the Micro turbine and ARS Units}

Two main flows are needed to evaluate the NPV of the project. The first is the capital outlay occurring at period 1 . This value is the cost of equipment and the installation of the

\begin{tabular}{|c|c|c|c|c|}
\hline Turbine Configuration & ARS HXE Cost [\$] & Micro turbine Cost [\$] & Digester/Biogas Production Equip [\$] & ARS [\$] \\
\hline T100CHP & 10,687 & 350,000 & $2,400,000$ & 76,700 \\
\hline $2 \times \mathrm{X} 65$ & 8,292 & 389,000 & $2,520,000$ & 76,700 \\
\hline $3 \times \mathrm{X} 65$ & 5,520 & 558,000 & $2,780,000$ & 76,700 \\
\hline $\mathrm{C200}$ & 4,289 & 564,000 & $2,800,000$ & 76,700 \\
\hline $4 \times C 65$ & 5,266 & 695,000 & $3,040,000$ & 76,700 \\
\hline C400 & 3,666 & $1,004,000$ & $3,600,000$ & 76,700 \\
\hline C600 & 3,585 & $1,321,000$ & $4,400,000$ & 76,700 \\
\hline $\mathrm{C800}$ & 2,910 & $1,539,000$ & $5,200,000$ & 76,700 \\
\hline C1000 & 2,626 & $1,751,000$ & $6,000,000$ & 76,700 \\
\hline
\end{tabular}
system. The second is the net profit occurring from the sale of electricity for each period, less the periodic maintenance costs for periods 1-20. The capital costs for each micro turbine configured with one ARS unit are listed in Table 6.

The cost for the heat exchangers is calculated based on their areas, as calculated in the EES model using the LMTD method and the pricing relation described by Smith (2005) assuming a carbon steel shell and aluminium tubes.

Table 6. Capital costs for a single ARS configured system and installation 
Table 7. Periodic cash flows for single ARS 250 cow farm

\begin{tabular}{ccccc}
\hline Turbine Configuration & GT Maintenance Cost [\$/year] & SalesFIT [\$/year] & SavingsGrid [\$/year] & Net cash flow [\$] \\
\hline T100CHP & $(17,520)$ & 116,584 & 21,596 & 120,660 \\
\hline 2 X C65 & $(19,993)$ & 159,223 & 21,596 & 160,826 \\
\hline 3 X C65 & $(29,990)$ & 264,562 & 21,596 & 256,168 \\
\hline C200 & $(30,379)$ & 272,665 & 21,596 & 303,882 \\
\hline 4 X C65 & $(39,986)$ & 319,915 & 21,596 & 478,167 \\
\hline C400 & $(59,568)$ & 516,139 & 21,596 & 662,203 \\
\hline C600 & $(91,139)$ & 731,746 & 21,596 & 895,614 \\
\hline C800 & $(119,136)$ & 993,154 & 21,596 & $1,116,532$ \\
\hline C1000 & $(151,898)$ & $1,246,834$ & 21,596 & \\
\hline
\end{tabular}

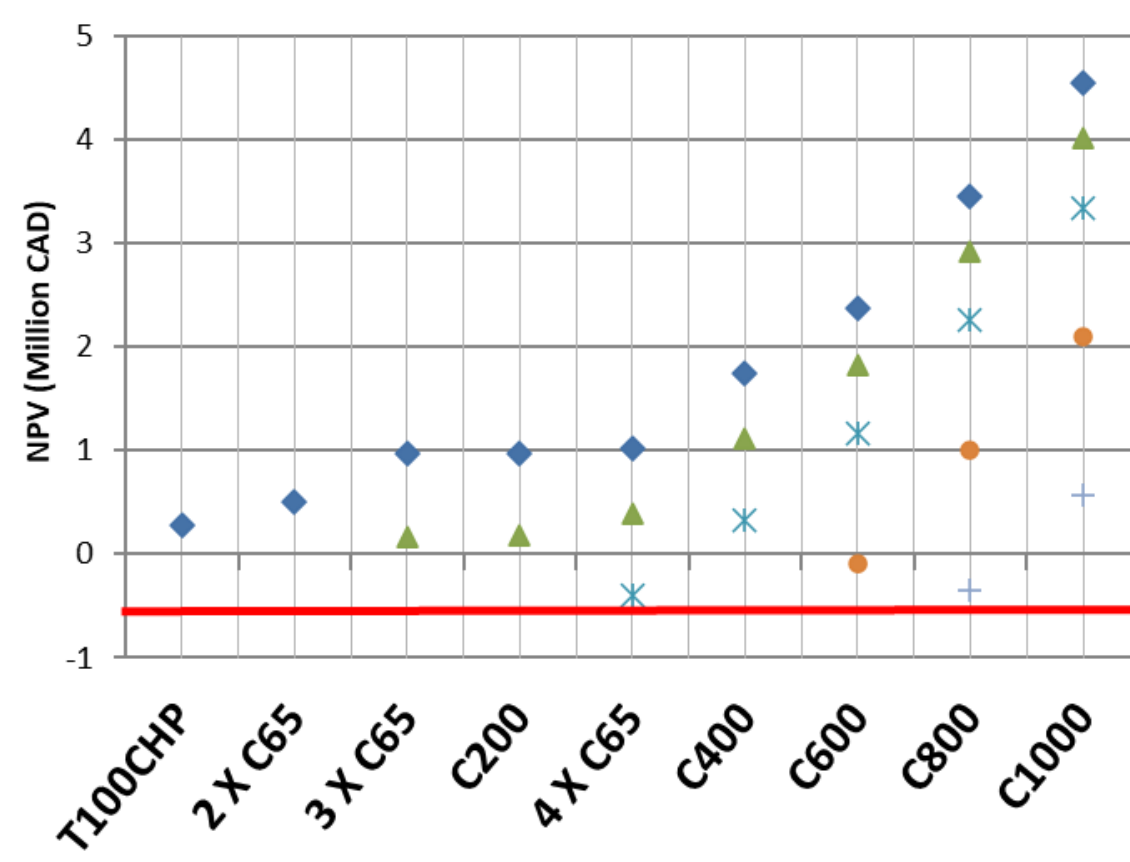

250 Cow Farm

500 Cow Farm

$\triangle 1000$ Cow Farm

$\times 1500$ Cow Farm

* 2000 Cow Farm

- 4000 Cow Farm

+6000 Cow Farm

Figure 2. Net present value of implementing each turbine system for the considered farm sizes

Based on information from Natural Resources Canada (2010), the price of the installed bio-digester and related piping and manure handling equipment ranges from around $\$ 2.4$ million for $100 \mathrm{~kW}$ installations to $\$ 6$ million for $1 \mathrm{MW}$ installations. A linear interpolation between the sizes is used to arrive at the cost of intermediate sized equipment.

The periodic costs considered here are maintenance costs. Periodic cash influxes from the project consist of electricity savings from not having to buy electricity from the grid, and the revenue from selling excess electricity to the grid through the FIT program.

The resulting periodic cash flows are listed for a single ARS configuration and a 250 cow farm in Table 7.

Similar tables are developed for all farm sizes and all turbine-ARS configurations that could support their own energy requirements. The NPVs for these projects are summarized in Figure 2.

Considering economics, one of two goals can be defined in the context of the presented problem for a given farm size:

1. What system is the most profitable over 20 years?

2. What systems can be installed to break even on the project, and still reap the strategic marketing benefits associated with the project?
These two situations guarantee the project will be profitable in some way, either strategically or financially and strategically.

Figure 2 addresses the two questions. It shows that any of the considered configurations for farm sizes of 4000 and 6000 cows are not profitable ventures. Farms of 2000 cows and under exhibit profitability when investing in the higher output turbine configurations of $\mathrm{C} 600$ and above.

The smaller 250 and 500 cow farms can just break even with the $\mathrm{C} 600$ unit. The larger the farm, the more energy it requires and consequently there is less energy available to sell to the grid. Cost wise, therefore, it is not feasible to implement these systems under the considered constraints for larger farm sizes.

\section{Calculations for the ORC Subsystem}

The NPV of selling electricity to the grid from operating an ORC off of each system configuration is presented in Figure 3. This NPV indicates the capital cost of the ORC subsystem to break even over the life of the FIT contract. Sources (Smith et $\mathrm{al}, 2007$ ) indicate that costs can be as little as $\$ 2500 / \mathrm{kWh}$ for newer ORC systems. For systems under $30 \mathrm{~kW}$ of output, this means capital costs could be lower than $\$ 75,000$, indicating profitability for many of the configurations. 


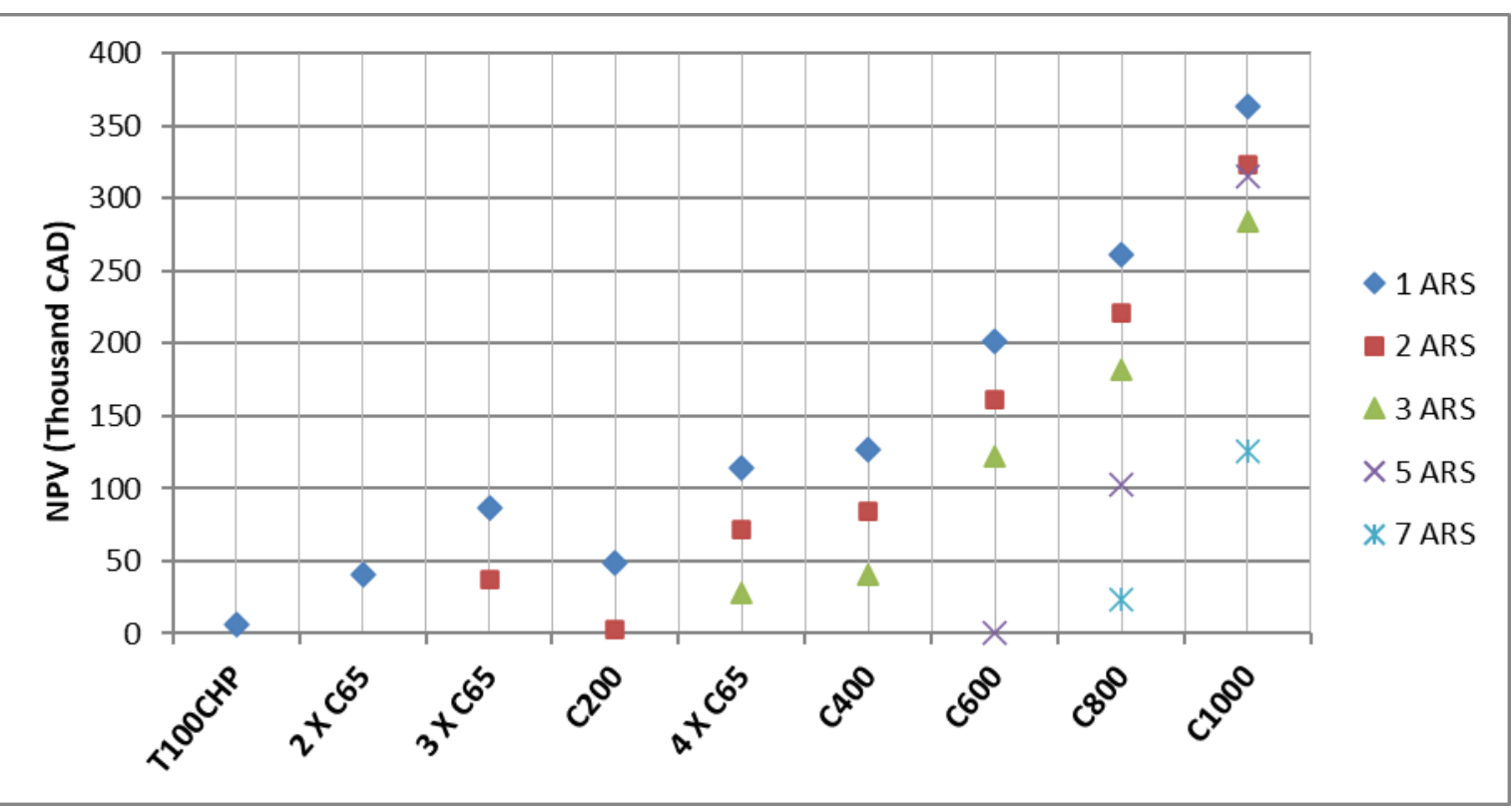

Figure 3. NPV for selling electricity generated from ORC for applicable system configurations

Table 8. Chemical composition of typical biogas and biogas selected for modelling purposes (Our Energy, 2012)

\begin{tabular}{ccc}
\hline Substance & $\begin{array}{c}\text { Typical } \\
\text { Concentration (\%) }\end{array}$ & $\begin{array}{c}\text { Selected } \\
\text { Concentration (\%) }\end{array}$ \\
\hline Methane, $\mathrm{CH}_{4}$ & $50-75$ & 60 \\
\hline Carbon dioxide, $\mathrm{CO}_{2}$ & $25-50$ & 35 \\
\hline Nitrogen, $\mathrm{N}_{2}$ & $0-10$ & 5 \\
\hline Hydrogen, $\mathrm{H}_{2}$ & $0-1$ & 0 \\
\hline Hydrogen sulfite, $\mathrm{H}_{2} \mathrm{~S}$ & $0-3$ & 0 \\
\hline Oxygen, $\mathrm{O}_{2}$ & $0-1$ & 0 \\
\hline
\end{tabular}

\section{ENVIRONMENTAL ANALYSIS}

Biogas is the result of anaerobic transformation of organic materials, such as bio-compostable waste, with the addition of anaerobic organisms. When biogas is produced, it contains primarily methane and carbon dioxide, but also can contain low concentrations of nitrogen, hydrogen, hydrogen sulfite and oxygen. The typical composition of biogas is presented in Table 8.

It is assumed that the required biogas for operating the MGT modules is generated by a bio-digester that operates on the manure generated from the cattle.

In this application, biogas is considered to be a renewable energy source that is carbon dioxide neutral with respect to the greenhouse gas balance. To obtain carbon dioxide neutrality, it is required to achieve low levels of emissions from combustion, as well as utilizing clean renewable energy sources for harvesting and transportation of the biogas (Loo and Koppejan, 2010).

From the combustion analysis, the MGTs require a high percentage of excess air. As seen from Figure 5, complete combustion occurs with a high percentage of excess air, resulting in a decrease of carbon dioxide and the absence of carbon monoxide in the combustion products. The excess air

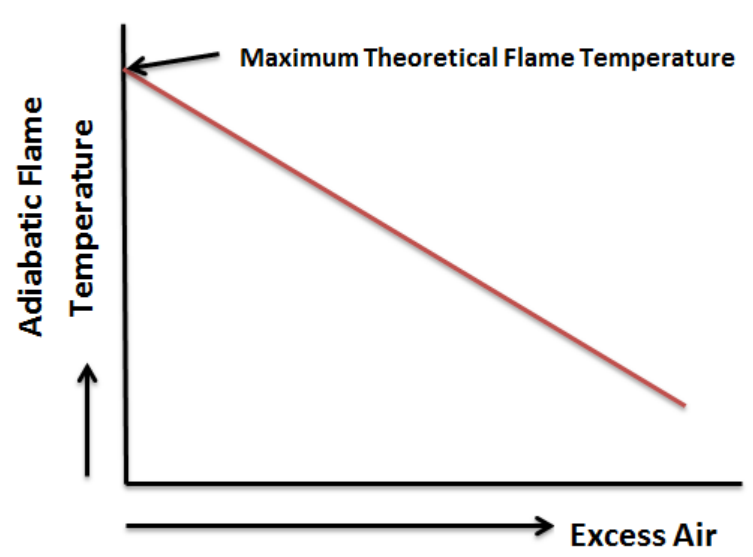

Figure 4. Variation of adiabatic flame temperature with excess air, modified from (Nag, 2008)

also controls the flame temperature inside of the combustion chamber and the turbine inlet temperature. A temperature too high jeopardizes the integrity of the combustion chamber, as well as the blades inside the turbine. The relationship between adiabatic flame temperature and excess air can be seen in Figure 4.

The mass flow rate of carbon dioxide from the MGT modules can be determined by the product of the mass fraction of $\mathrm{CO}_{2}$ and the mass flow rate of combustion exhaust. That is,

$$
\dot{m}_{\mathrm{CO}_{2}}=m f_{\mathrm{CO} 2} \cdot \dot{m}_{\text {gas }}
$$

The rate at which carbon dioxide is produced is correlated to the number of cows for a given farm size. Therefore, the quantity of carbon dioxide released in the atmosphere is determined in kilograms per cow over the span of a year, as follows:

$$
\mathrm{CO}_{2} \text { production per cow }=\frac{\dot{m}_{\mathrm{CO}_{2}}}{\text { Farm Size }} \cdot\left|\frac{3600 \mathrm{~s}}{1 \mathrm{~h}}\right| \cdot\left|\frac{8760 \mathrm{~h}}{1 \text { year }}\right|
$$

Although the biogas utilized in this application is considered to be carbon neutral, minimizing the amount of carbon dioxide emitted to the atmosphere is still considered 


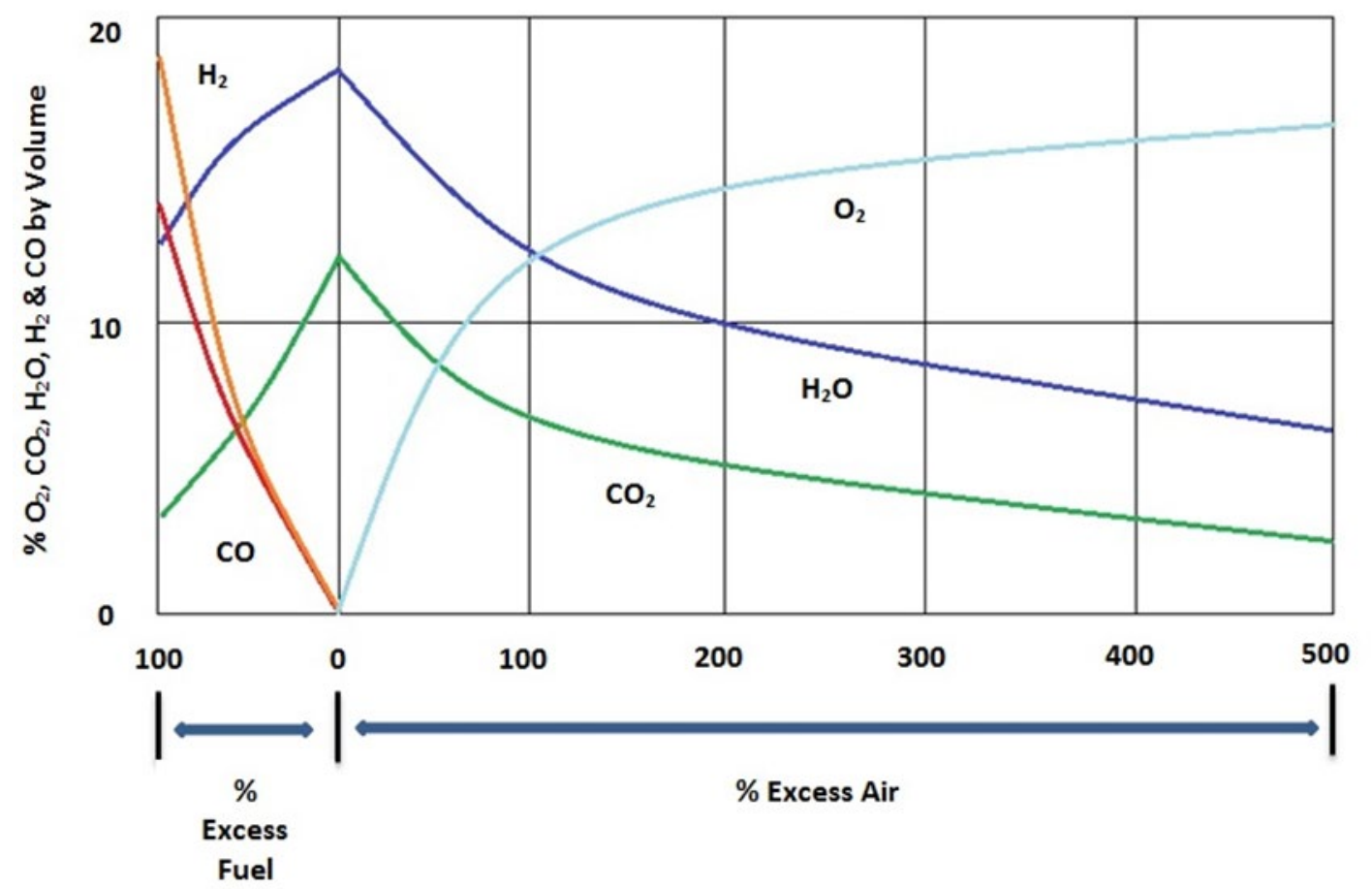

Figure 5. Trends of combustion products relative to excess air, modified from (Kissock et al, 2007)

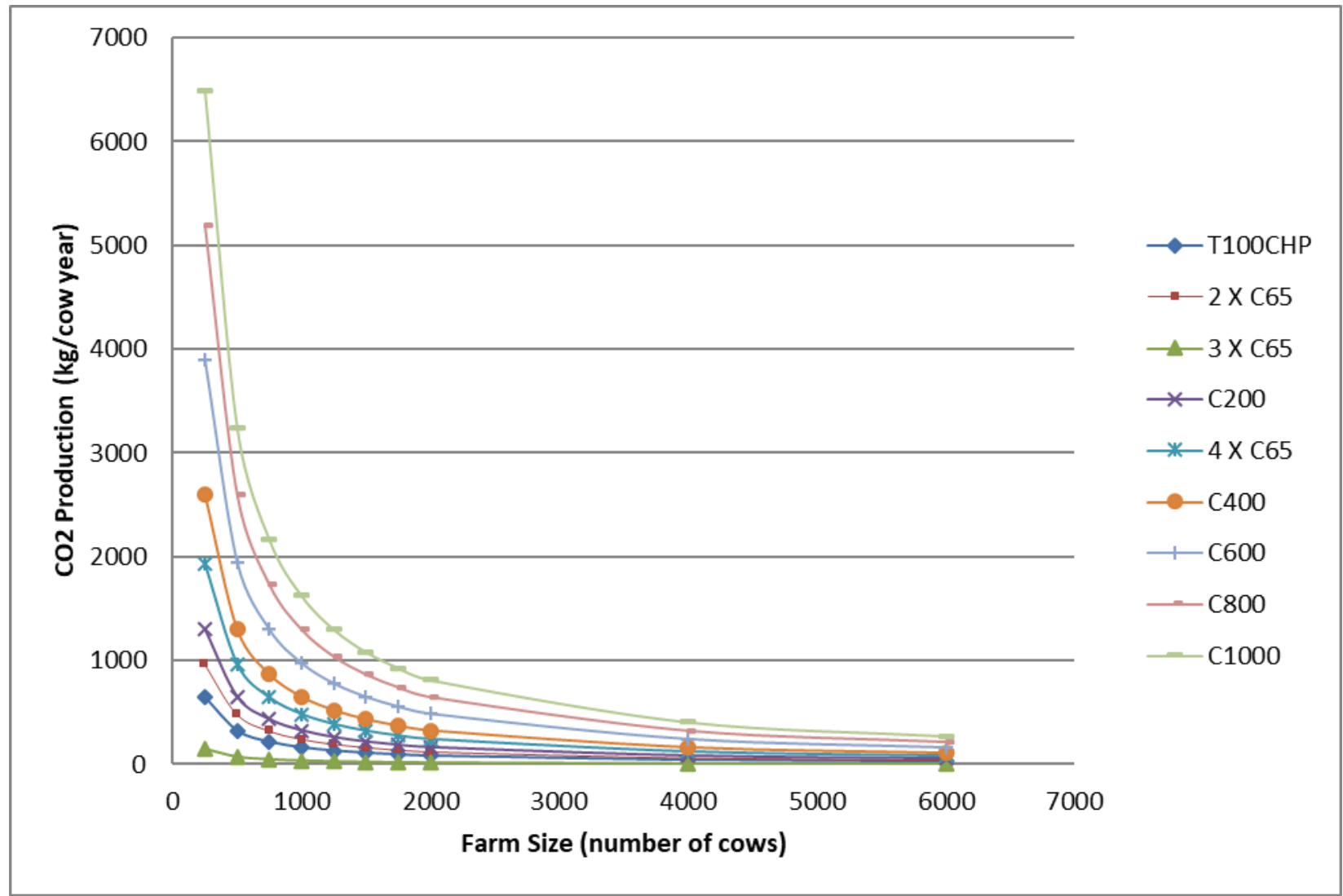

Figure 6. Rate of carbon dioxide production based on farm size

for this application. From Figure 6, as the size of the turbine module is oversized to maximize profits from generating electricity, the rate at which carbon dioxide is produced is also maximized. To minimize the amount of carbon dioxide released into the environment a turbine with the lowest emissions is tailored to meet only the electrical demand of the farm and not to generate electricity for profit. In Figure 7, the unit mass of carbon dioxide produced (in kilogram per kilowatt hour) is specified for each turbine module. The mass of carbon dioxide per unit of electricity generated (in kilowatt hour) can be expressed as:

$$
\mathrm{CO}_{2} \text { production per } \mathrm{kWh}=\frac{\dot{m}_{\mathrm{CO}_{2}}}{\dot{W}_{M G T, N E T}} \cdot\left|\frac{3600 \mathrm{~kJ}}{1 \mathrm{kWh}}\right|
$$

The most environmentally benign system configuration is obtained by using the lowest carbon dioxide producing MGT, 


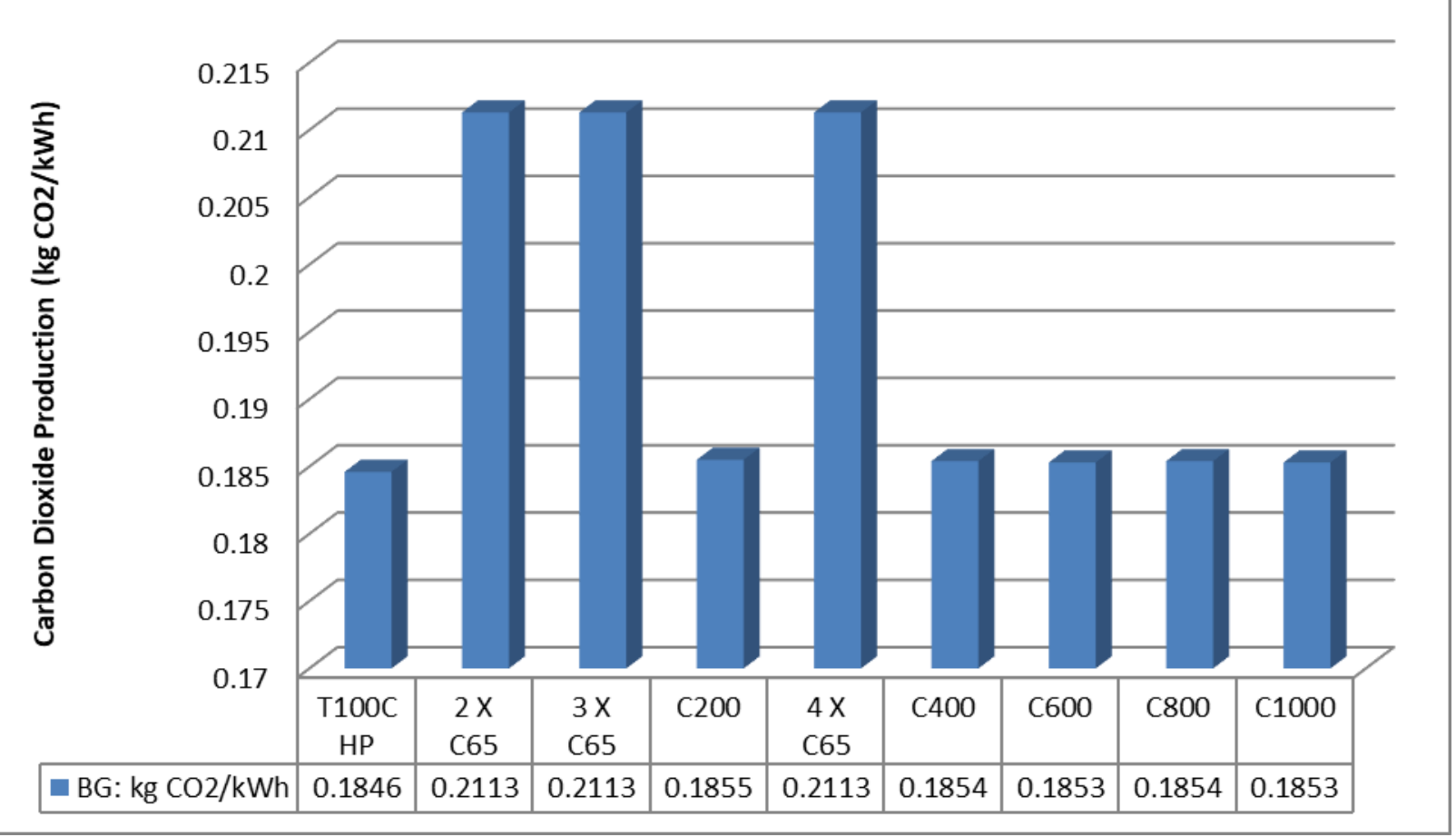

Figure 7. Comparison of $\mathrm{CO} 2$ production for each MGT configuration

Table 9. Recommended configurations for financially viable farm sizes

\begin{tabular}{ccccc}
\hline Farm Size & Turbine & nARS & NPV of project & CO2 Emissions $\left(\mathbf{k g ~ C O} \mathbf{~ k W h}^{-\mathbf{1}}\right)$ \\
\hline 250 & $\mathrm{C} 800$ & 1 & $\$ 1,426,131$ & 0.1854 \\
\hline 500 & $\mathrm{C} 800$ & 1 & $\$ 1,281,487$ & 0.1854 \\
\hline 1000 & $\mathrm{C} 800$ & 2 & $\$ 961,068$ & 0.1854 \\
\hline 1500 & $\mathrm{C} 800$ & 2 & $\$ 685,519$ & 0.1854 \\
\hline 2000 & $\mathrm{C} 800$ & 3 & $\$ 364,500$ & 0.1854 \\
\hline
\end{tabular}

sized so as to fit the maximum number of cows and to not produce excess electricity for sale to the grid.

The MGT that produces that least amount of carbon dioxide is the T100 CHP, as seen in Figure 7. The number of cows can be calculated by dividing the capacity of the turbine by the power required for a single cow. The T100 CHP has the potential to provide for the needs of 870 cows. The cooling load required for this configuration necessitates the use of one absorption refrigeration unit with very little excess cooling.

It is important to note in Figure 7 that the carbon dioxide produced by each of the C200, C400, C600, C800 and C1000 units is very similar to that of the T100 CHP. These modules do not technically minimize the production of carbon dioxide, since they are not the lowest producers of carbon dioxide, but they are still able to achieve low carbon dioxide emissions.

Environmental performance is optimized when the net output of the system just matches the energy requirement of the farm, and produces no excess electricity. Thus, to minimize the environmental impact, but remain financially viable, the configurations in Table 9 are suggested for farm sizes under 2000 cows.

\section{CONCLUSIONS}

Economic and environmental analyses are carried out of a grid-independent environmentally benign dairy farm in
Ontario, Canada. It is found that farm sizes between 250 and 6000 cows can have cooling and electricity needs met with a micro gas turbine ranging in capacity from 100 to $1000 \mathrm{~kW}$ output while maintaining similar energy and exergy efficiencies. The economic and environmental analyses demonstrate the financial feasibility as well as the environmental impact of this type of multi-generational energy system.

Since the most environmentally benign turbine, the T100CHP, is incapable of supporting more than one ARS unit, its use is limited. For the $\mathrm{C} 200-\mathrm{C} 1000$ range, the next best in terms of environmental performance, the C800 and C1000 units can support all farm sizes considered (up to seven absorption refrigeration systems) and have positive net present values for farm sizes under 2000 cows.

Environmental performance is maximized when the net output of the system satisfies the dairy farm's energy requirement and produces no excess electricity. Several configurations are able to minimize environmental impact but remain financially viable, for farm sizes under 2000 cows. While these are the suggested configurations according to this study, further investigation of a wider range of turbine units, different ARS units and other heat recovery options (other ORC units) appears to be merited to provide more comprehensive options. 


\section{NOMENCLATURE}

$\begin{array}{ll}\dot{Q} & \text { heat transfer rate } \\ \dot{W} & \text { work rate } \\ \dot{m} & \text { mass flow rate } \\ \bar{S} & \text { specific entropy (mol) } \\ h & \text { specific enthalpy (mass) } \\ A F & \text { air-fuel ratio } \\ M & \text { molar mass } \\ T & \text { temperature } \\ g & \text { gravitational constant } \\ m & \text { mass } \\ m f & \text { mass fraction } \\ n & \text { number of moles } \\ q & \text { specific heat transfer } \\ s & \text { specific entropy }\end{array}$

\section{GREEK LETTERS}

$\eta \quad$ energy efficiency

\section{SUBSCRIPTS}

\begin{tabular}{|c|c|}
\hline 0 & ambient condition \\
\hline$A$ & air \\
\hline$A R S$ & absorption refrigeration system \\
\hline$b$ & boundary \\
\hline$B C$ & bottoming cycle \\
\hline$B G$ & biogas \\
\hline cool & cooling effect \\
\hline$C$ & cold boundary condition \\
\hline$C C$ & combustion chamber \\
\hline СOMP & compressor \\
\hline$C O N D$ & condenser \\
\hline ext & external boundary \\
\hline gas & exhaust gases \\
\hline$f$ & fuel \\
\hline$H$ & hot boundary condition \\
\hline$H X$ & heat exchanger \\
\hline int & internal boundary \\
\hline$M G T$ & micro gas turbine \\
\hline NET & net output \\
\hline$O R C$ & organic Rankine cycle \\
\hline$P$ & product gases \\
\hline PUMP & pump \\
\hline REGEN & regenerator \\
\hline$S Y S$ & overall system \\
\hline$T C$ & topping cycle \\
\hline$U R B$ & turbine \\
\hline
\end{tabular}

\section{ACKNOWLEDGEMENTS}

The authors gratefully acknowledge the financial support provided by the Natural Sciences and Engineering Research Council of Canada.

\section{REFERENCES}

Capper, J. L. and Cady, R. A. (2020). The effects of improved performance in the U.S. dairy cattle industry on environmental impacts between 2207 and 2017. Journal of Animal Science, 98(1), skz291. https://doi.org/10.1093/jas/ skz291

Capstone Turbine Corporation, (2012). Capstone Turbine Corporation Solutions, Capstone Turbine Corporation. Available at: http://www.capstoneturbine.com/prodsol/ solutions/chp.asp

Clarke, S. and House, H. (2010). Using Less Energy on Dairy Farms. Ministry of Agriculture, Food and Rural Affairs, Ontario.

Collins, D. (2011). Competitive Advantages of being Ecofriendly. In Business Ethics: How to Design and Manage Ethical Organizations (pp. 345-346). New York: Wiley.

Cuomo, M. A., Kool, E., Reddy, B. V. and Rosen, M. A. (2018a). Energy modelling and analysis of a multi-generation renewable energy system for dairy farm applications, Biofuels. https://doi.org/10.1080/17597269.2018.1469342

Cuomo, M. A., Kool, E., Reddy, B. V. and Rosen, M. A. (2018b). Multi-generation renewable energy system for dairy farms: Exergy analysis, European Journal of Sustainable Development Research, 2(3), 37. https://doi.org/10.20897/ ejosdr/2669

Hettiarachchia, M. H. D., Mihajlo, G., William, M. W. and Yasuyuki, I. (2006). Optimum design criteria for an Organic Rankine cycle using low-temperature geothermal heat sources, Energy, 32(9), 1698-1706. https://doi.org/10.1016/ j.energy.2007.01.005

Hydro One. (2012). Rates \& Prices. Available at: http://www.hydroone.com/RegulatoryAffairs/RatesPrices/ Pages/default.aspx

Kissock, K., Carpenter, K. and D’Antonio, M. (2007). Common excess air rends in industrial boilerswith single- point positioning control and strategies to optimize efficiency. 2007 ACEEE Summer Study on Enery Efficiency in Industry.

Loo, S. V. and Koppejan, J. (2010). The Handbook of Biomass Combustion \& Co-firing. Washington: Earthscan.

Nag, P. K. (2008). Power Plant Engineering. New Delhi: Tata McGraw-Hill.

Natural Resources Canada. (2010). Country Biogas Report. Available at: http://www.iea-biogas.net/files/datenredaktion/download/publications/country-reports/2010/ Canada_Country_Report_11-2010.pdf

Ontario Power Authority. (2012). FIT Program Pricing. Available at: http://fit.powerauthority.on.ca/fit-programpricing 
Our Energy. (2012). Biofuels. Available at: http://www.ourenergy.com/biofuels.html

Segerkvist, K. V., Hansson, H., Sonesson, U. and Gunnarsson, S. (2020). Research on environmental, economic and social sustainability in dairy farms: A systematic mapping of current literature. Sustainability, 12(14), 5502. https://doi.org/10.3390/su12145502

Smith, I. K., Stosic, N., Kovacevic, A. and Langson, R. (2007). Cost Effective ORC Heat recovery Systems for Power Recovery from Low Enthalpy Geothermal Sources, Transactions, Geothermal Resource Council 31, January.

Smith, R. (2005). Chemical Process Design and Integration. New York: Wiley. https://doi.org/10.1002/0471238961. chemsmit.a01

SolarNext AG. (2008). Chillii ACC50 - Absorption Chiller,"06. Available at: www.solarnext.de
Sorguven, E. and Ozilgen, M. (2012). Energy utilization, carbon dioxide emission, and exergy loss in flavored yogurtproduction process. Energy, 40(1), 214-225. https://doi.org/10.1016/j.energy.2012.02.003

Spachos, T. and Stamatis, A. (2011). Thermal analysis and optimization of an anaerobic treatment system of whey. Renewable Energy, 36(8), 2097-2105. https://doi.org/ 10.1016/j.renene.2011.01.020

Turbec. (2012). Turbec Products. Available at: http://www.turbec.com/products/products.htm

Yildirim, N. and Genc, S. (2015). Thermodynamic analysis of a milk pasteurization process assisted by geothermal energy. Energy, 90(1), 987-996. https://doi.org/10.1016/j.energy. 2015.08.003

Yildirim, N. and Genc, S. (2017). Energy and exergy analysis of a milk powder production system. Energy Conversion and Management, 149, 698-705. https://doi.org/10.1016/ j.enconman.2017.01.064 